\title{
Medical factors determining the quality of life of patients with Crohn's disease
}

\section{Czynniki medyczne determinujące jakość życia pacjentów z chorobą Leśniowskiego-Crohna}

\author{
Kamila Rachubińska ${ }^{1}$, Dorota Wnuk², Alicja Jeżuchowska ${ }^{1}$, Dominika Kaska ${ }^{1}$, Anita Rybicka ${ }^{3}$, \\ Szymon Grochans ${ }^{4}$, Marzanna Stanisławska ${ }^{3}$, Elżbieta Grochans ${ }^{3}$ \\ 'Doctoral Studies, Pomeranian Medical University, Szczecin, Poland \\ Head of the Studies: Elżbieta Grochans PhD, Prof. PMU \\ ${ }^{2}$ Student Scientific Circle at the Nursing Department, Faculty of Health Sciences, Pomeranian Medical University, Szczecin, Poland \\ Head of the Department: Elżbieta Grochans, PhD, Prof. PMU \\ ${ }^{3}$ Department of Nursing, Faculty of Health Sciences, Pomeranian Medical University, Szczecin, Poland \\ Head of the Department: Elżbieta Grochans, PhD, Prof. PMU \\ ${ }^{4}$ Student, Warsaw University Medical, Warsaw, Poland \\ Dean of the University: Prof. Mirosław Wielgoś MD, PhD
}

Key words: quality of life, Crohn's disease, medical factors.

Słowa kluczowe: jakość życia, choroba Leśniowskiego-Crohna, czynniki medyczne.

\begin{abstract}
Introduction: Crohn's disease is a chronic condition that affects the functioning and life of the patients. Quality of life of patients affected by the disease is of particular importance because it allows better functioning in all dimensions of life. It is essential to identify the numerous factors that affect the patients' of quality of life.

Aim of the research: To search for medical factors that influence the quality of life of patients affected by Crohn's disease. Material and methods: The study was conducted using a diagnostic survey. The study group comprised 100 adult patients with Crohn's disease hospitalised in the Gastroenterology Clinic of the Autonomous Public Hospital Complex No.1 of Pomeranian Medical University in Szczecin. The study was conducted in accordance with the Declaration of Helsinki. The standardised quality of life questionnaire SF-36v2 and an original questionnaire were used. The collected data were statistically analysed.

Results: The analysis demonstrated a statistically significant effect of disease duration on quality of life as regards social functioning and mental health $(p<0.05)$. The course of the disease was found to affect all domains and dimensions of quality of life $(p<0.05)$. Treatment modality had a statistically significant influence only on the domain of physical functioning $(p<0.05)$. The number of hospitalisations in the year preceding the study was found to have a significant effect only on particular domains $(p<0.05)$.

Conclusions: The course of the disease had the most significant effect on the quality of life of patients with Crohn's disease.
\end{abstract} Other significant factors are determining the tailored method of treatment and disease duration.

\section{Streszczenie}

Wprowadzenie: Choroba Leśniowskiego-Crohna należy do przewlekłych schorzeń, które wpływają na funkcjonowanie i życie chorych. Duże znaczenie ma dobra jakość życia chorych, ponieważ umożliwia lepsze funkcjonowanie we wszystkich wymiarach. Istotne jest poznanie różnych czynników, które wpływają na ocenę jakości życia.

Cel pracy: Określenie czynników, które oddziałują na jakość życia pacjentów z chorobą Leśniowskiego-Crohna.

Materiał i metody: Badania prowadzono metoda sondażu diagnostycznego wśród 100 dorosłych pacjentów z chorobą Leśniowskiego-Crohna hospitalizowanych w Klinice Gastroenterologii Samodzielnego Publicznego Szpitala Klinicznego nr 1 Pomorskiego Uniwersytetu Medycznego w Szczecinie, zgodnie z zasadami deklaracji helsińskiej. Zastosowano standaryzowany kwestionariusz do oceny jakości życia SF-36v2 oraz kwestionariusz w formie własnej ankiety. Zebrany materiał poddano analizie statystycznej.

Wyniki: Wykazano statystycznie istotny wpływ czasu trwania choroby na ocenę jakości życia w zakresie funkcjonowania społecznego i zdrowia psychicznego $(p<0,05)$. Przebieg choroby oddziaływał na wszystkie domeny i wymiary jakości życia 
$(p<0,05)$, natomiast metoda leczenia statystycznie istotnie wpływała tylko na funkcjonowanie fizyczne $(p<0,05)$. Liczba hospitalizacji badanych w ostatnim roku miała istotny wpływ tylko w wybranych domenach $(p<0,05)$.

Wnioski: Przebieg choroby w największym stopniu oddziaływał na jakość życia pacjentów z chorobą Leśniowskiego-Crohna. Istotnymi czynnikami były metoda leczenia oraz czas trwania choroby.

\section{Introduction}

Crohn's disease is characterised by a transmural inflammatory process, which may affect any part of the gastrointestinal tract from the mouth to the anus. This increasingly common disease mostly affects young people entering adulthood. The experience of being diagnosed with a chronic disease can be traumatic because the patient must learn to live with the life-long disease [1].

Once a chronic disease is recognised and diagnosed, the patient is affected by it throughout their entire life. Crohn's disease can negatively affect dayto-day functioning of patients leading to a decline in the quality of life and disease acceptance.

Nowadays, contemporary medicine and nursing is concerned not only with providing treatment but also with improving the quality of life of patients suffering from a chronic condition. There are several components of global quality of life, namely: the somatic state, general physical condition, mental wellbeing, emotions, and social relations. Assessment of the quality of life provides an insight into aggravation of disease symptoms experienced by the patient and the extent of the negative effects it may have on the comfort of everyday life. The World Health Organisation (WHO) defines the quality of life as 'the individuals' perception of their position in life in the context of the culture and value systems in which they live, and in relation to their goals, expectations, standards, and concerns" [2]. In medicine and nursing, the concept of the quality of life relates to specific domains, i.e. physical, mental, and social domains - dimensions of health. In the era of intense scientific progress and continued development of new therapies, the process of effective treatment is focused not only on maintaining the health of patients but also correlates with factors such as: satisfying the basic living needs of patients, providing a sense of security and mental wellbeing in accordance with Maslow's hierarchy of needs [3].

\section{Aim of the research}

The aim of the study was to search for medical factors (course of the disease, treatment modality, duration of the disease, the number of hospitalisations) determining the quality of life of patients suffering from Crohn's disease.

\section{Material and methods}

The study was conducted in 2017 in the Gastroenterology Clinic of the Autonomous Public Hospital Complex No. 1 of the Pomeranian Medical University in Szczecin. Prior to conducting the research, writ- ten consent was obtained from the aforementioned health institution. The study was conducted in accordance with the Declaration of Helsinki. The research received a positive opinion from the Bioethical Commission on 7.06.2016.

The study group comprised 100 patients suffering from Crohn's disease (55 women, 45 men). A diagnostic survey with the following research tools was used for the purpose of obtaining the study material: an original questionnaire containing questions regarding the socio-demographic and selected medical data, and the SF-36v2 health survey concerned with subjective health assessment containing 34 questions belonging to eight categories. The quality of life index is the sum of points obtained in all eight scales. It allows the general assessment of health. The categories are grouped into two scales, i.e. the physical and mental dimensions of life quality. The analysed categories represent the dimensions that have been particularly affected by the disease.

\section{Statistical analysis}

Data was collected and subjected to preliminary calculations and modification using a Microsoft Excel 2007 PL spreadsheet. The statistical analysis was performed with the use of IBM SPSS ver. 22 software. The assessment of conformity of distribution of the analysed quantitative features with the normal distribution was done using Shapiro-Wilk test. Pearson's $r$ correlation coefficient was applied when all the scales were quantitatively calculated and the distribution of the variables were close to normal distribution. When the assumptions of normality of distribution or ordinal character of the variables were not met, Spearman's correlation coefficient was used. For the data showing normal distribution or non-parametric data, Kruskal-Wallis ANOVA was used. The aforementioned are used for testing observations that are determined by one or more simultaneous factors. The level of statistical significance was set at $p<0.05$.

\section{Results}

\section{Description of the study group}

The study group was varied in terms of gender of the participants. More than half of the study group were females (55\%). Most of the patients, i.e. $45 \%$, were residents of cities of up to 100,000 in population. The majority of the study group, i.e. $40 \%$, declared to be involved in a non-marital relationship. The age at di- 
agnosis of Crohn's disease ranged from 12 to 54 years, with a mean of $24.4 \pm 8.1$ years. The duration of the disease was from one month to 27 years and 2 months. Mean duration of the disease was $7.8 \pm 4.6$ years. More than half of the respondents, i.e. $53 \%$, were diagnosed 5-9 years prior to the study. In terms of the number of cases of disease exacerbation per year, $41 \%$ of patients were in remission. Complications of Crohn's disease occurred in $15 \%$ of patients (anal fistula). In terms of treatment modality, $66 \%$ of patient underwent mixed treatment. The average number of hospitalisations among the patients with Crohn's disease in the year preceding the study was $2.3 \pm 3.6$. In the study group, the number of hospitalisations ranged from 0 to 33 . Thirty percent of the study group required hospitalisation only once (Table 1).

Table 1. Description of the test group

\begin{tabular}{|c|c|c|}
\hline Parameter & $N$ & $\%$ \\
\hline \multicolumn{3}{|l|}{ Sex: } \\
\hline Woman & 55 & 55 \\
\hline Men & 45 & 45 \\
\hline \multicolumn{3}{|l|}{ Age [years]: } \\
\hline $18-19$ & 5 & 5 \\
\hline $20-29$ & 33 & 33 \\
\hline $30-39$ & 45 & 45 \\
\hline $40-49$ & 29 & 29 \\
\hline 50 and more & 2 & 2 \\
\hline \multicolumn{3}{|l|}{ Marital status: } \\
\hline Informal relationship & 40 & 40 \\
\hline Formal relationship & 35 & 35 \\
\hline Free & 25 & 25 \\
\hline \multicolumn{3}{|l|}{ Education: } \\
\hline Basic & 2 & 2 \\
\hline Professional education & 57 & 57 \\
\hline Secondary education & 18 & 18 \\
\hline Higher & 23 & 23 \\
\hline \multicolumn{3}{|c|}{$\begin{array}{l}\text { Structure of the course of Crohn's disease in the } \\
\text { study participants }\end{array}$} \\
\hline Variable: & $N$ & $\%^{*}$ \\
\hline Tightening up to $3 \times$ a year & 31 & 31 \\
\hline Hardenings above $3 \times$ a year & 9 & 9 \\
\hline Remission of the disease & 41 & 41 \\
\hline $\begin{array}{l}\text { Presence of complications (perirectal } \\
\text { fistulas) }\end{array}$ & 15 & 15 \\
\hline No complications & 9 & 9 \\
\hline Other & 4 & 4 \\
\hline
\end{tabular}

The analysis of data concerning the quality of life obtained with the use of SF-36v2 health survey showed that the highest quality of life was identified in the following domains: physical condition -78.5 \pm 17.2 points, role limitations due to emotional state - $74.17 \pm 20.12$ points, role limitations in physical functioning - $63.38 \pm 20.37$, and the physical dimension of the quality of life. The participants obtained the lowest results concerning the following: vitality, general health condition, and social functioning. Apart from determining eight domains of quality of life, SF-36v2 was used to assess two domains: in the physical dimension the mean score was $61.41 \pm 16.11$ points, and in the mental domain it was $55.40 \pm 11.19$, which indicates impaired functioning regarding this dimension.

\begin{tabular}{|c|c|c|}
\hline Variable & $N$ & \%* \\
\hline \multicolumn{3}{|c|}{ Structure of the applied treatment in Crohn's disease: } \\
\hline Steroid therapy & 8 & 8 \\
\hline Immunosuppression & 11 & 11 \\
\hline Mixed & 66 & 66 \\
\hline Biological treatment & 27 & 27 \\
\hline Surgical treatment - surgery & 9 & 9 \\
\hline Other & 1 & 1 \\
\hline \multicolumn{3}{|c|}{$\begin{array}{l}\text { Structure of the duration of Crohn's disease in } \\
\text { Leśniowski: }\end{array}$} \\
\hline Less than 5 years & 24 & 24 \\
\hline $5-9$ years & 53 & 53 \\
\hline $10-15$ years & 17 & 17 \\
\hline Over 15 years & 6 & 6 \\
\hline
\end{tabular}

Structure of the number of hospitalisations due to Crohn's disease:

\begin{tabular}{lll}
\hline 0 & 21 & 21 \\
\hline 1 & 30 & 30 \\
\hline 2 & 66 & 66 \\
\hline 3 & 15 & 15 \\
\hline 4 and more & 14 & 13
\end{tabular}

The structure of the age at diagnosis of Crohn disease - Crohn's disease:

\begin{tabular}{lcc|}
\hline Below 20 years old & 30 & 30 \\
\hline Between 20 and 29 years old & 46 & 46 \\
\hline Between 30 and 39 years old & 17 & 17 \\
\hline Over 40 years old & 7 & 7 \\
\hline
\end{tabular}

$N$-number; ${ }^{*}$ multiple choice question, percentages do not add up. 
The analysis showed a statistically significant effect of the duration of disease on the assessment of quality of life in terms of social functioning $(p=0.04)$ and mental health $(p=0.024)$. This correlation is negative and its strength is weak but pronounced. The longer the patient had been affected by Crohn's disease, the lower was the score of quality of life in the aforementioned domains. As for the remaining domains, duration of the disease showed no influence on the assessment of quality of life $(p>0.05)$.

It was found that the course of the disease had a significant effect on the quality of life in all domains and dimensions as identified with SF-36v2. Statistically significant differences were found between the scores of quality of life. The patients in remission or without any complications of Crohn's disease exhibited much better quality of life than the patients who experienced three or more cases of disease exacerbation in a year. By far the lowest score in terms of quality of life was found in the patients with more than three cases of disease exacerbation in a year $(p<0.05)$ (Table 2).

The analysis revealed that treatment modality had a statistically significant effect on the quality of life of patients with Crohn's disease in terms of physical functioning. The patients undergoing steroid therapy obtained the highest scores in this domain of quality of life $(\mathrm{Me}=95)$. The patients undergoing immunosuppressive and mixed treatment showed poorer functioning $(\mathrm{Me}=85)$, similarly to the patients after biological treatment $(\mathrm{Me}=72.5)$. The worst quality of life score in terms of physical functioning was iden- tified among surgically treated patients $(\mathrm{Me}=67.5)$; $(p=0.01)$. As for the remaining spheres and dimensions of quality of life, no statistically significant differences due to modality of treatment were found $(p>0.05)$ (Table 3).

The analysis showed a statistically significant difference in terms of the number of hospitalisations in the year preceding the study and the quality of life in the dimension of physical functioning $(p=0.002)$, role limitations in physical functioning $(p<0.001)$, bodily pain $(p<0.001)$, general health $(p=0.001)$, and the physical dimension of quality of life $(p<0.001)$. This correlation is negative and its strength is weak but pronounced. An increase in the number of hospitalisations has a negative impact on the quality of life in terms of physical functioning, role limitations in physical functioning, bodily pain, and general health. The strength of the relationship between the number of hospitalisations in the year preceding the study and the physical dimension of quality of life is high $(r=-0.416)$. The analysis showed that quality of life of patients in the study group markedly decreases with an increase in the number of hospitalisations in a year. As for the remaining domains, the number of hospitalisations showed no effect on the assessment of quality of life $(p>0.05)$ (Table 4$)$.

\section{Discussion}

Crohn's disease is a chronic and incurable condition characterised by alternating periods of relapse and remission. The vast array of intestinal as well as non-intestinal symptoms accompanying the disease

Table 2. Correlation between the course of the disease and quality of life (SF-36V2) of patients with Crohn's disease

\begin{tabular}{|c|c|c|c|c|c|c|c|}
\hline \multirow{2}{*}{$\begin{array}{l}\text { Quality } \\
\text { of life }\end{array}$} & \multicolumn{5}{|c|}{ Course of the disease } & \multicolumn{2}{|c|}{ ANOVA Kruskal-Wallis } \\
\hline & $\begin{array}{l}\text { Up to } \\
3 \text { relapses } \\
\text { per year } \\
\text { Median }\end{array}$ & $\begin{array}{l}\text { More than } \\
3 \text { relapses } \\
\text { per year } \\
\text { Median }\end{array}$ & $\begin{array}{l}\text { Remission } \\
\text { Median }\end{array}$ & $\begin{array}{l}\text { With compli- } \\
\text { cations } \\
\text { Median }\end{array}$ & $\begin{array}{l}\text { No compli- } \\
\text { cations } \\
\text { Median }\end{array}$ & $H$ & $P$-value \\
\hline PF & 70 & 60 & 90 & 82.5 & 75 & 19.437 & 0.001 \\
\hline $\mathrm{RP}$ & 62.5 & 37.5 & 75 & 50 & 87.5 & 21.742 & $<0.001$ \\
\hline $\mathrm{BP}$ & 37.5 & 25 & 75 & 62.5 & 62.5 & 28.622 & $<0.001$ \\
\hline $\mathrm{GH}$ & 36.5 & 31.5 & 51.5 & 51.5 & 51.5 & 14.802 & 0.005 \\
\hline VT & 31.25 & 25 & 43.75 & 50 & 56.25 & 16.101 & 0.003 \\
\hline SF & 50 & 50 & 50 & 62.5 & 50 & 14.369 & 0.006 \\
\hline $\mathrm{RE}$ & 75 & 50 & 83.33 & 66.67 & 100 & 11.695 & 0.020 \\
\hline $\mathrm{MH}$ & 45 & 35 & 60 & 55 & 65 & 12.577 & 0.014 \\
\hline $\mathrm{FH}$ & 50.69 & 41.25 & 71.94 & 64.28 & 68.19 & 27.284 & $<0.001$ \\
\hline $\mathrm{MH}$ & 49.17 & 40 & 57.5 & 59.01 & 67.81 & 15.338 & 0.004 \\
\hline
\end{tabular}

$P F-$ physical functioning, $R P$ - role limitations in physical functioning, $B P$ - bodily pain, $G H$ - general health, VT - vitality, SF - social functioning, RE - role limitations due to emotional state, $\mathrm{MH}$ - mental health, $\mathrm{FH}$ - physical dimension of quality of life, $\mathrm{MH}-\mathrm{mental}$ dimension of quality of life, $H$-ANOVA Kruskal-Wallis test, $p$ - statistical significance coefficient. 
Table 3. Correlation between treatment modality and quality of life (SF-36v2) of patients with Crohn's disease

\begin{tabular}{|lcccccccc|}
\hline $\begin{array}{l}\text { Quality } \\
\text { of life }\end{array}$ & \multicolumn{4}{c}{ Treatment modality } & \multicolumn{3}{c|}{ ANOVA Kruskal-Wallis } \\
\cline { 2 - 11 } & $\begin{array}{c}\text { Steroid } \\
\text { therapy } \\
\text { Median }\end{array}$ & $\begin{array}{c}\text { Immuno- } \\
\text { suppres- } \\
\text { sion } \\
\text { Median }\end{array}$ & $\begin{array}{c}\text { Mixed } \\
\text { Median }\end{array}$ & $\begin{array}{c}\text { Biological } \\
\text { Median }\end{array}$ & $\begin{array}{c}\text { Surgical } \\
\text { Median }\end{array}$ & $H$ & $\mathrm{~d} f$ & $P$-value \\
PF & 95 & 85 & 85 & 72.5 & 67.5 & 13.287 & 4 & 0.01 \\
RP & 68.75 & 62.5 & 68.75 & 50 & 50 & 7.736 & 4 & 0.102 \\
BP & 62.5 & 50 & 62.5 & 50 & 43.75 & 2.87 & 4 & 0.58 \\
GH & 56.5 & 30.75 & 51.5 & 46.5 & 20.75 & 6.892 & 4 & 0.142 \\
VT & 50 & 37.5 & 37.5 & 43.75 & 18.75 & 4.585 & 4 & 0.333 \\
SF & 56.25 & 50 & 50 & 50 & 50 & 2.412 & 4 & 0.661 \\
RE & 58.33 & 70.83 & 75 & 75 & 70.83 & 2.027 & 4 & 0.731 \\
MH & 52.5 & 57.5 & 50 & 65 & 45 & 5.207 & 4 & 0.267 \\
FH & 70.69 & 62.06 & 65.84 & 58.31 & 45.5 & 9.286 & 4 & 0.054 \\
MH & 54.27 & 54.74 & 57.14 & 61.93 & 46.15 & 3.931 & 4 & 0.415 \\
\hline
\end{tabular}

PF - physical functioning, RP - role limitations in physical functioning, BP - bodily pain, GH - general health, VT - vitality, SF - social functioning, $R E$ - role limitations due to emotional state, $\mathrm{MH}$ - mental health, $\mathrm{FH}$ - physical dimension of quality of life, $\mathrm{MH}-\mathrm{mental}$ dimension of quality of life, $\mathrm{H}$ - ANOVA Kruskal-Wallis test, $p$ - statistical significance coefficient.

may lead to disability not only in the physical domain but also in the psychosocial sphere [4].

The study clearly demonstrates that patients in remission are characterised by a higher assessment of quality of life as compared with patients who experienced at least one exacerbation of the disease. The results obtained in the course of this study are in line with the findings by other authors. Spanish researchers, Casellas et al., conducted studies in several hospitals and confirmed that quality of life is lower in patients during relapse as compared with those in remission [5]. There are also Polish studies by Andrzejewska et al. focusing on the analysis of overall quality of life among patients with Crohn's disease. The results of statistical analysis included therein showed that decreased quality of life is characteristic for patients who are in an active phase of the disease rather than in remission [6]. However, different results were obtained by Rubin et al., who conclude that the phase of a disease experienced by a patient has no significant effect on the quality of life. In this study, the quality of life was found to be significantly reduced both in patients who were in remission as well as those in relapse [7]. When commenting on the aforementioned results it is important to take into consideration the influence of the frequency of hospitalisation, occurrence of intestinal symptoms, and treatment modalities offered to patients in different phases of the disease on the quality of life. In the results obtained by researchers from Warsaw, Jakubowski et al. clearly demonstrate the consistent and increasing trend in the frequency of hospitali-
Table 4. Correlation between the number of hospitalisations in the year preceding the study and quality of life (SF-36v2) of patients with Crohn's disease

\begin{tabular}{|lcc|}
\hline Variable & $r$ & $P$-value \\
Physical functioning & -0.309 & 0.002 \\
$\begin{array}{l}\text { Role limitation in physical } \\
\text { functioning }\end{array}$ & -0.399 & $<0.001$ \\
Bodily pain & -0.351 & $<0.001$ \\
General health & -0.338 & 0.001 \\
Vitality & -0.185 & 0.065 \\
Social functioning & 0.071 & 0.483 \\
Limitations due to emotional state & -0.134 & 0.183 \\
Mental health & -0.158 & 0.117 \\
$\begin{array}{l}\text { Physical dimension of quality } \\
\text { of life }\end{array}$ & -0.416 & $<0.001$ \\
Mental dimension of quality of life & -0.161 & 0.11 \\
\hline
\end{tabular}

$p$ - statistical significance coefficient, $r$ - Spearman's correlation coefficient.

sations due to Crohn's disease, particularly in men aged 0-39 years. Among women, an increase in the number of hospitalisations due to Crohn's disease was recorded in the period 2003-2007 [8]. Also, data obtained as part of our own research based on the analysis of medical records of patients with Crohn's disease treated in the Gastroenterology Clinic of Pomeranian Medical University in Szczecin show an increasing trend in the number of hospitalisations 
in a year. Each hospitalisation of a patient suffering from Crohn's disease is most commonly due to exacerbation of symptoms. This translates into a given number of days on which the patient is temporarily unable to work and, consequently, needs to rely on sickness benefit. Such a situation, which is beyond the control of the patient, seems to have a profoundly negative effect on quality of life $[9,10]$.

As was demonstrated in our own research, another factor that affects quality of life of patients with Crohn's disease is treatment modality. The participants of the present study undergoing steroid therapy as a treatment of choice showed a much higher level of quality of life as compared with patients who underwent surgical procedure. The analysis of the influence of the method of treatment on the quality of life of Crohn's disease patients by ChrobakBien et al. produced the same results [11]. Moreover, the study by Baczyk et al. indicates that quality of life is lower in patients who received surgical treatment as compared to patients receiving conservative treatment in an internal medicine department [12]. Further consideration of the factors that might have a negative effect on quality of life must also include the occurrence of intestinal and non-intestinal clinical symptoms. According to Casellas et al., bodily pain and discomfort greatly affect the quality of life of patients. More than half of the respondents (65.9\%) experienced abdominal pain and discomfort during the active phase of the disease [13]. Moreover, Sakson-Słomińska et al. observed that the frequency of experienced intestinal symptoms had a negative effect on quality of life - the level of quality of life was found to decrease with increasing frequency of the symptoms [14]. Schirbel et al. conducted a study on 179 patients suffering from Crohn's disease and concluded that abdominal pain is a significant factor leading to decreased quality of life, regardless of the phase of the disease [15].

In multidisciplinary therapy of Crohn's disease, apart from pharmacological, surgical, and psychological treatment, an important role is played by nutritional therapy, which is at times omitted or neglected. Nutritional treatment helps to maintain remission and, when applied improperly, can contribute to aggravation of symptoms, shorten the remission period, and negatively affect the quality of life [16]. The results of our own studies do not confirm the effect of diet used in IBD I and II on the patients' quality of life because most of the respondents (63\%) followed and adhered to the dietary recommendations. Also, the study by Marcinkowska et al. shows that nutritional status had no influence on quality of life of the respondents [17]. Nutritional therapy is an important element of treatment, both in terms of prevention as well as treatment of secondary malnutrition and correcting the waterelectrolyte, acid-base, and vitamin imbalance [18]. According to Grzybowska, there is a strong correlation between the intake of carbohydrates and lipids and simultaneously occurring reduced consumption of fruit, vitamin $\mathrm{C}$, and magnesium and occurrence of symptoms of Crohn's disease [16].

The analysis of the results obtained in the course of the present study clearly shows that the participants were characterised by decreased functioning in the mental dimension (55.40 \pm 11.19$)$, as compared with the physical dimension of quality of life $(61.41 \pm 16.11)$. A similar view was presented by a group of Swedish researchers, who concluded that the most frequent complaint reported by the participants suffering from Crohn's disease was related to lack of vitality and exacerbation of symptoms, particularly bodily pain [19].

\section{Conclusions}

Disease activity has a negative effect on quality of life during relapse. The need for hospitalisation results in a reduced social role of the patients. Treatment modality has an effect on the quality of life of patients affected by Crohn's disease. The benefits of conservative treatment translate into a physical functioning dimension of quality of life and outweigh the benefits of invasive treatment.

\section{Conflict of interest}

The authors declare no conflict of interest.

\section{References}

1. Maksymiuś-Kłos A. Gastroenterologia. Nieswoiste zapalenia jelit. Prakt Lek 2015; 8: 22-23.

2. Chojnacka-Szawłowska G. Uwarunkowania adaptacji do przewlekłej choroby. In: Psychologiczne aspekty przewlekłych chorób somatycznych. Chojnacka-Szawłowska G (ed.). Wydawnictwo Vizja Press i It, Warsaw 2012; 27-35.

3. Banovic I, Gilibert D, Cosnes J. Crohn's disease and fatigue: constancy and co-variations of activity of the disease, depression, anxiety and subjective quality of life. Psych Health Med 2010; 15: 394-405.

4. Gotlib J, Belowska J, Panczyk M, Sienkiewicz Z, Wójcik G. Wiedza i postawy pielęgniarek wobec wykorzystywania wyników badań naukowych w codziennej praktyce klinicznej - doniesienie wstępne. Probl Pielęg 2014; 22: 281-287.

5. Casellas F, Arenas JI, Baudet JS. Impairment of health related quality of life in patients with inflammatory bowel disease: a Spanish multicenter study. Inflamm Bowel Dis 2005; 11: 488-496.

6. Andrzejewska J, Talarska D, Mochalak M, Linke K. Quality of life in patients with Crohn's disease and ulcerative colitis. Comperative analysis. Prz Gastroenterol 2009; 4: 251-255.

7. Rubin G, Hungin A, Chinn D, Dwarakanath D. Quality of life in patients with establishedd inflammatory bowel disease: UK general practice survey. Aliment Pharmacol Ther 2004; 19: 529-535.

8. Jakubowski A, Zagórowicz E, Kraszewska E, Bartnik W. Zwiększenie częstości hospitalizacji z powodu nieswo- 
istych chorób zapalnych jelit w Polsce. Pol Arch Med Wew 2014; 124: 190-193.

9. Wójcik B, Loga K, Włodarczyk M, Sobolewska-Włodarczyk A, Padysz M, Wiśniewska-Jarosińska M. Extraintestinal manifestations of Crohn's disease. Gastroenterol Rev 2016; 11: 218-221.

10. Wiśniewska-Jarosińska M, Rudnicki C. Powikłania i trudności terapeutyczne w chorobie Leśniowskiego-Crohna. Terapia 2010; 6: 73-75.

11. Chrobak-Bień J, Gawor A, Paplaczyk M, Małecka-Panas E, Gąsiorowska A. Wpływ akceptacji choroby na jakość życia pacjentów z chorobą Leśniowskiego-Crohna. Nowa Med 2017; 1: 5-17.

12. Bączyk G, Karoń J, Krokowicz P. Obiektywny i subiektywny wymiar jakości życia osób z nieswoistym zapaleniem jelit leczonych na oddziale chirurgicznym. Prz Gastroenterol 2011; 6: 170-175.

13. Casellas F, Arenas JI, Baudet JS. Impairment of health-related quality of life in patients with inflammatory bowel disease: a Spanish multicenter study. Inflamm Bowel Dis 2005; 11: 488-496.

14. Sakson-Słomińska A, Wasielewska Z, Szaflarska-Poplawska A, Krogulska A. Czy słabo nasilone bóle brzucha moga być jedynym objawem rozwijającej sie choroby Leśniowskiego-Crohna? Opis przypadku. Pediatr Med Rodz 2016; 12: 445-450.

15. Schirbel A, Reichert A, Roll S. Impact of pain on health-related quality of life in patients with inflammatory bowel disease. World J Gastroenterol 2010; 16: 3168-3177.

16. Grzybowska Z. Zasady żywienia w nieswoistych zapaleniach jelit. Ter Gastroenterol 2008; 2: 34-36.

17. Marcinkowska E, Grzymisławski M, Swora-Cwynar E, Dobrowolska-Zachwieja A. Wpływ stanu odżywienia pacjentów z nieswoistymi zapalnymi chorobami jelit na jakość ich życia. Pielęg Zdr Publ 2013; 3: 241-248.

18. Kargulewicz A, Stankowiak-Kulpa H, Grzymisławski M. Rola leczenia żywieniowego $\mathrm{w}$ chorobie Leśniowskiego-Crohna. Gastroenterol Pol 2010; 17: 300-303.

19. Piche T, Ducrotte P, Sabate M, Coffin B, Zerbib F, Dapoigny M. Impact of functional bowel symptoms on quality of life and fatigue in quiescent Crohn disease and irritable bowel syndrome. Neurogastroenterol Motil 2010; 22: 626-632.

\section{Address for correspondence:}

\section{Kamila Rachubińska}

Doctoral Studies

Pomeranian Medical University

ul. Żołnierska 48, 71-210 Szczecin, Poland

Phone: +48 721596764

E-mail: k.rachubinska@gmail.com 